\title{
Cesarean combined with tubal sterilization: some medical and demographic aspects
}

\author{
Sergei V. Jargin 1
}

${ }^{1}$ Peoples' Friendship University of Russia. Moscow, Russia. E-mail: sjargin@mail.ru

The aim of this letter was a brief literature overview of recent publications on the cesarean section $(\mathrm{CS})^{1}$ and cesarean tubal ligation, where CS is combined with tubal sterilization, analyzing this topic from the clinical and demographical viewpoints. The tubal sterilization is a reliable method of birth control. The cesarean tubal ligation has an advantage of avoiding additional incisions and anesthesia.2 A systematic performance of the cesarean tubal ligation could be an efficient birth control method, also counteracting the gender imbalance in some regions. For example, in China, the male-to-female ratio at birth is elevated, while the ratio was reported to increase considerably with the age and number of parities, being very high in non-primipara. 3 The gender imbalance at birth was reported also from India and other countries; more details and references are in. 4,5

The majority of women are pleased with their decision to be sterilized. ${ }^{6}$ Patients are much more likely to regret declining a tubal ligation during unplanned CS $(40 \%)$ than regret accepting one $(2.5 \%) .{ }^{7}$ The female sterilization has been associated with a decreased risk of endometrioid and serous ovarian cancers 8 and probably has a positive impact upon sexuality. ${ }^{9}$ The advantage of elective CS is the relatively low risk of fetal injury as well as the negative association with neonatal mortality and morbidity. Some reports on enhanced maternal morbidity and mortality are probably biased as they confound CS with conditions related to maternal death not depending on the mode of delivery.10,11 Accordingly, CS may be a marker of pre-existing morbidities or older age rather than a risk factor of itself. 12 Moreover, in regard to certain maternal complications e.g. pelvic floor injury and urinary incontinence, elective CS was reported to be protective compared to vaginal delivery and emergent CS. 13,14 Admittedly, CS is more costly and associated with higher risks in conditions of limited medical facilities. The bleeding associated with CS is a problem that still requires attention; CS is a potential underlying factor in puerperal sepsis, thromboembolism and eclampsia.15 However, surgical procedures generally tend to improve. In more developed countries, CS is widely regarded as a safe intervention owing to mastered surgical techniques, improved anesthesia, infection and thrombosis prophylaxis. ${ }^{16}$ Finally, granted requests for elective CS were reported to be associated with decreased postpartum depression rates. ${ }^{17}$

There seems to be some conservatism and bias in favor of vaginal delivery also in the professional literature. For example, it was claimed that the "overuse of SC adversely affects the health of the mother and the child"18 with references.19,20 However, there are no such or similar statements in the articles. 19,20 Analogously, it was stated that "morbidity and mortality [associated with CS is] more often than [that associated with] vaginal delivery" 21 with references, among others, to the 
sources. 22,23 These articles are about the vaginal birth after SC, 22,23 which is a different topic. An indirect evidence in favor of a biased attitude to CS is the frequently mentioned association of CS with long-term offspring outcomes such as asthma, diabetes mellitus type 1 and gastrointestinal diseases, although the evidence is poor. 16 The proposed mechanisms through which CS could impact the immune system are obscure and largely hypothetical e.g. impaired bacterial colonization of the intestine. ${ }^{16}$ If it is so indeed, the lacking exposure to certain microorganisms at CS could be compensated by probiotics. ${ }^{24}$

\section{Conclusion}

The cesarean tubal ligation should be generally considered for women not planning further pregnancies. Certainly, the latest delivery is not necessarily the last one, since circumstances may change after

\section{References}

1. Filho MB, Rissin A. WHO and the epidemic of cesarians Rev Bras Saúde Matern Infant. 2018; 18: 3-4.

2. Mahadevappa K, Prasanna N, Channabasappa RA. Trends of various techniques of tubectomy: A five year study in a tertiary institute. J Clin Diagn Res. 2016; 10: QC04-7.

3. Huang Y, Tang W, Mu Y, Li X, Liu Z, Wang Y, Li M, Li Q, Dai L, Liang J, Zhu J. The sex ratio at birth for 5,338,853 deliveries in China from 2012 to 2015: a facility-based study. PLoS One. 2016; 11: e0167575.

4. Jargin SV. Overpopulation and modern ethics. S Afr Med J. 2009; 99: 572-3.

5. Jargin SV. Letter to the Editor. Int J Risk Saf Med. 2016; 28 (3): 171-4.

6. Contraception by female sterilisation. Br Med J. 1980; 280 1154-5.

7. Verkuyl DA. Sterilisation during unplanned caesarean sections for women likely to have a completed family should they be offered? Experience in a country with limited health resources. BJOG. 2002; 109: 900-4.

8. Walker JL, Powell CB, Chen LM, Carter J, Bae Jump VL, Parker LP, Borowsky ME, Gibb RK. Society of Gynecologic Oncology recommendations for the prevention of ovarian cancer. Cancer. 2015; 121: 2108-20.

9. Shah MB, Hoffstetter S. Contraception and sexuality. Minerva Ginecol. 2010; 62: 331-47.

10. Kilsztajn S, Carmo MS, Machado LC Jr, Lopes ES, Lima LZ. Caesarean sections and maternal mortality in Sao Paulo. Eur J Obstet Gynecol Reprod Biol. 2007; 132: 64-9.

11. Nomura RM, Alves EA, Zugaib M. Maternal complications associated with type of delivery in a university hospital. Rev Saúde Pública. 2004; 38: 9-15. the delivery, including socio-economic settings or death of a child. The age, attitude of the male partner etc. should be taken into account in decisions about recommendations. However, CS on maternal request must be available also in the absence of contraindications for attempting vaginal delivery. This pertains also to Russia, where CS is normally not performed on a maternal request. 25 Certain experts reported that they had performed CS on maternal request and that countrywide CS is performed more frequently when the procedure is paid on by patients. ${ }^{26}$ Others insist that SC must be done only in accordance with indications. In the author's opinion, the tripling of the global index of deliveries performed by CS over the period $1980-2016$ (from 6 to $18.6 \%)^{1}$ is a positive development. A more frequent use of the cesarean tubal ligation would be especially favorable for overpopulated regions with a gender imbalance.

12. Lydon-Rochelle M, Holt VL, Easterling TR, Martin DP. Cesarean delivery and postpartum mortality among primiparas in Washington State, 1987-1996(1). Obstet Gynecol. 2001; 97: 169-74.

13. Salim R, Shalev E. Health implications resulting from the timing of elective cesarean delivery. Reprod Biol Endocrinol. 2010; 8: 68

14. Di Stefano M, Caserta D, Marci R, Moscarini M. Urinary incontinence in pregnancy and prevention of perineal complications of labour. Minerva Ginecol. 2000; 52: 30712

15. Moodley J, Fawcus S, Pattinson R. Improvements in maternal mortality in South Africa. S Afr Med J. 2018; 108(3 Suppl. 1): S4-S8

16. Stordeur S, Jonckheer P, Fairon N, De Laet C. Elective caesarean section in low - risk women at term: consequences for mother and offspring. Health technology assessment. KCE Report 275, 2016.

17. Olieman RM, Siemonsma F, Bartens MA, Garthus-Niegel $\mathrm{S}$, Scheele F, Honig A. The effect of an elective cesarean section on maternal request on peripartum anxiety and depression in women with childbirth fear: a systematic review. BMC Pregnancy Childbirth. 2017; 17: 195.

18. Liang J, Mu Y, Li X, Tang W, Wang Y, Liu Z, Huang X, Scherpbier RW, Guo S, Li M, Dai L, Deng K, Deng C, Li Q, Kang L, Zhu J, Ronsmans C. Relaxation of the one child policy and trends in caesarean section rates and birth outcomes in China between 2012 and 2016: observational study of nearly seven million health facility births. BMJ. 2018; 360: k817.

19. Blustein J, Liu J. Time to consider the risks of caesarean delivery for long term child health. BMJ. 2015; 350: h2410. 
20. Belizán JM, Althabe F, Cafferata ML. Health consequences of the increasing caesarean section rates. Epidemiol. 2007 18: 485-6.

21. Dhai A, Gardner J, Guidozzi Y, Howarth G, Vorster M. Vaginal deliveries - is there a need for documented consent? S Afr Med J. 2011; 101: 20-2.

22. Rageth JC, Juzi C, Grossenbacher H. Delivery after previous cesarean: a risk evaluation. Obstet Gynec. 1999; 93: 332-7.

23. Hibbard JC, Ismail MA, Wang Y, Te C, Karrison T, Ismail MA. Failed vaginal birth after a cesarean section: how risky is it? Maternal morbidity. Am J Obstet Gynecol. 2001; 184: $1365-71$.
24. Hashemi A, Villa CR, Comelli EM. Probiotics in early life: a preventative and treatment approach. Food Funct. 2016; 7: $1752-68$.

25. Likhachev VK. Operative obstetrics with a phantom course Moscow: MIA; 2014 (Russian).

26. Cherhukha EA. Is cesarean section at a pregnant woman's will justified? Akush Ginekol (Mosk); 2002; (6): 3-7 (Russian).

Received on July 2, 2018

Approved on July 12, 2018 